\title{
ANALISIS PERENCANAAN DAN PERTANGGUNGJAWABAN APBDES MENURUT PERATURAN MENTERI DALAM NEGERI NOMOR 113 TAHUN 2014 DALAM UPAYA MENINGKATKAN PEMBANGUNAN DESA
}

\author{
Vega Virjinia Orangbio $^{1}$, Jantje Tinangon ${ }^{2}$, Natalia Gerungai ${ }^{3}$ \\ ${ }^{123}$ Fakultas Ekonomi dan Bisnis . Jurusan Akuntansi. Universitas Sam Ratulangi, Jl. Kampus Bahu, Manado, \\ 95115, Indonesia
}

E-mail :vegavirjiniaorangbio26@gmail.com

\begin{abstract}
Village financial management is the whole activity which includes planning, implementation, reporting and accountability of village finances. A sound management of village finances must be managed in accordance with the rules and principles and human resource capabilities that implement them. The purpose of this study is to analyze the suitability of financial management in two inobonto villages with the rules of the minister of home affairs number 113 of 2014 which includes the activities of planning, implementation, and accountability by using qualitative descriptive research method. The results showed the regulation of the minister of home affairs number 113 of 2014 on the management of village finance in the village inobonto two subdistricts bolaang mongondow not fully implemented according to existing rules. For financial planning and execution activities in two village inobonto, not yet transparent information to the public on the budget of village expenditure income. The village financial management system in the village of inobonto 2 has not yet used the village financial system (SISKEUDES). So it is expected that in the village financial management activities in the next budget year should use the village financial system.
\end{abstract}

Keywords: Village financial planning, village financial implementation, village financial accountability, APBDes Permendagri No.113 Year 2014.

\section{PENDAHULUAN}

\subsection{Latar Belakang}

Perkembangan suatu negara tidak lain sangat dipengaruhi oleh pimpinan dalam memimpin atau memerintah negara yang didudukinya. Di Indonesia pemerintahan terbagi atas pemerintah pusat dan pemerintah daerah yang dimana masing-masing mempunyai tugas dan tanggungjawab sesuai dengan jabatannya yang diamanatkan.

Berdasarkan Undang-undang No. 23 Tahun 2014 tentang Pemerintah Daerah disebutkan dalam Bab 1 pasal 1 ayat 2 bahwa Pemerintahan Daerah adalah penyelenggaraan urusan pemerintahan oleh pemerintah daerah dan dewan perwakilan rakyat daerah berdasarkan asas otonomi dan tugas pembantuan dengan prinsip otonomi seluas-luasnya dalam sistem dan prinsip Negara Kesatuan Republik Indonesia Tahun 1945. Pada ayatnya yang ke 3 menjelaskan bahwa pemerintah daerah adalah kepala daerah sebagai kepala penyelenggara Pemerintah Daerah yang memimpin pelaksanaan pemerintahan yang kewenangan daerah otonom.

Berdasarkan juga Undang-Undang No. 23 Tahun 2014 tentang Pemerintah Daerah juga disebutkan dalam Bab 1 Pasal 1 Ayat 6 bahwa otonomi daerah adalah hak, wewenang, dan kewajiban daerah otonom mengatur dan mengurus sendiri urusan pemerintahan, dan kepentingan masyarakat setempat dalam sistem Negara Kesatuan Republik Indonesia. Pelaksanaan otonomi daerah didasarkan atas pertimbangan bahwa daerah lebih mengerti bahkan mampu serta mengetahui kebutuhan masyarakat didaerahnya. Salah satu aspek yang sangat penting untuk diperhatikan dalam pelaksanaan otonomi daerah dan desentralisasi adalah masalah pengelolaan keuangan daerah yang biasa dikenal dengan Anggaran 
Pendapatan Belanja Daerah (APBD), dimana pelaksanaaan pengelolaan ini harus dilaksanakan secara hati-hati serta harus berdasarkan peraturan yang telah ditetapkan.

Selain Aggaran Pendapatan dan Belanja Daerah (APBD) dalam pelaksanaan otonomi daerah terdapat juga pengelolaan Anggaran Pendapatan dan Belanja Desa (APBDes) yang diolah secara berhati-hati serta berdasarkan peraturan yang sudah ditetapkan. APBDes merupakan rencana keuangan tahunan pemerintahan desa, yang dimana didalamnya tertuang konsep pemerintah desa untuk mencapai tujuan dalam membangun dan mengatur desanya (Musdzalifah, 2016 : 2). Pelaksanaan APBDes dilakukan oleh Pemerintah Desa sendiri dimana Pemerintah Daerah sudah memberi kewenangan yang penuh kepada desa untuk mengelola keuangannya secara bertanggungjawab. Salah satu tugas dan tanggungjawab yang sangat penting bagi pemerintah desa yaitu mengelola keuangan desa secara baik dan bertanggungjawab.

Pedesaan merupakan bagian integral dari Negara Republik Indonesia. Membangun desa berarti membangun sebagian besar penduduk Indonesia, hal ini mudah dimengerti karena lebih dari delapan puluh persen penduduk Indonesia tersebar di desa-desa seluruh Indonesia. Dalam sebuah desa terdapat pemerintah desa yang bertugas dan bertanggungjawab menyelenggarakan tugas pemerintahannya seperti dengan definisinya dalam Undang-Undang No 6 Tahun 2014 bahwa Pemerintah Desa adalah kepala desa atau yang disebut dengan nama lain dibantu perangkat desa sebagai unsur penyelenggara pemerintah desa. Selain kepala desa, perangkat desa terdiri dari sekretaris, bendahara dan kepala seksi atau kepala urusan sesuai dengan kebutuhan kelengkapan desa.

Menurut Taufik Kurrohman (2015:1) Dalam pemerintahan semua tingkatan, mulai dari tingkat nasional sampai dengan desa. Salah satu bentuk desentralisasi adalah pemerdayaan masyarakat desa dalam pengelolaan keuangan. Dalam PERMENDAGRI NO. 113 Tahun 2014 menjelaskan bahwa, Keuangan Desa adalah semua hak dan kewajiban desa yang dapat dinilai dengan uang serta segala sesuatu berupa uang dan barang yang berhubungan dengan pelaksanaan hak dan kewajiban desa. Keuangan desa harus dikelola berdasarkan asas-asas transparan, akuntabel, partisipatif serta dilakukan secara tertib dan disiplin anggaran. Menurut Paluku Kazimoto (2013:2) meningkatkan transparan dan akuntabel keuangan desa harus disiapkan informasi secara baik serta diinformasikan kepada masyarakat bahkan stakeholder lewat papan desa ataupun media yang lain.

Dalam pengelolaan keuangan desa yang baik harus berdasarkan sesuai dengan pedoman yang telah diatur oleh pemerintah yakni dalam PERMENDAGRI No. 113 Tahun 2014 tentang pengelolaan keuangan desa yang mencakup 5 poin penting yaitu perencanaan, pelaksanaan, penatausahan, pelaporan dan pertanggungjawaban.

Berdasarkan pemaparan singkat latar belakang masalah di atas, penulis tertarik untuk meneliti tentang"Analisis Perencanaan dan Pertanggungjawaban APBDes Menurut Peraturan Menteri Dalam Negeri Nomor 113 Tahun 2014 Dalam Upaya Meningkatkan Pembangunan Desa".

\subsection{Tujuan Penelitian}

Adapun tujuan yang ingin dicapai dalam penelitian ini Untuk menganalisis proses perencanaan dan pertanggungjawaban APBDesa Inobonto II sudah sesuai dengan Permendagri No.113 Tahun 2014.

\section{TINJAUAN PUSTAKA}

\subsection{Konsep Akuntansi Pemerintahan}

Akuntansi pemerintahan merupakan bidang ilmu akuntansi yang saat ini sedang berkembang pesat. Tuntutan transparasi dan akuntabilitas publik atas dana-dana masyarakat yang dikelolah pemerintah memunculkan kebutuhan atas penggunaan akuntansi dalam 
mencatat dan melaporkan kinerja pemerintahan. Sebagai salah satu bidang dalam ilmu akuntansi, definisi akuntansi pemerintahan tidak akan terlepas dari pemahaman tentang akuntansi itu sendiri, termasuk perkembangannya di Indonesia. Sedangkan pengertian Pemerintahan, meskipun tampaknya konotasi lembaga politik lebih menonjol, aspek ekonominya tidak dapat dikesampingkan. (Deddy, Iswahyudi dan Maulidah, 2012:1

\subsection{Tujuan Akuntansi Pemerintahan}

Pada umumnya tujuan akuntansi pemerintahan adalah menyajikan informasi bagi para pengambil keputusan tentang kejadian-kejadian ekonomi yang penting dan mendasar serta membantu mempersiapkan informasi tentang bagaimana cara mereka mengalokasikan sumber-sumber yang serba terbatas seperti modal, tenaga kerja, tanah dan bahan baku guna untuk mencapai tujuan yang diinginkan oleh pemerintah. Sedangkan bagi manajemen, bagaimana mereka mengalokasikan sumber-sumber dana dan berbagai proyek alternatif sehingga menyebabkan manajemen keputusan atas dasar perasaan dan bukan atas dasar rasionalitas.

Menurut Abdul Halim (2010:29) akuntansi pemerintahan mempunyai beberapa tujuan yaitu:

\section{Pertanggunjawaban (Accountability and stewardship)}

Tujuan pertanggungjawaban memiliki arti memberikan informasi keuangan yang lengkap, cermat dalam bentuk dan waktu yang tepat, yang berguna bagi pihak yang bertanggung jawab yang berkaitan dengan operasi unit-unit pemerintahan. Lebih lanjut, tujuan pertanggungjawaban ini mengharuskan tiap orang atau badan yang mengelola keuangan Negara harus memberikan pertanggunjawaban atau perhitungan.

2. Manajerial

Tujuan manajerial berarti bahwa akuntansi pemerintah harus menyediakan informasi keuangan yang diperlukan untuk perencanaan, penganggaran, pelaksanaan, pemantauan, pengendalian anggaran, perumusan kebijaksanaan dan pengambilan keputusan, serta penilaian kinerja pemerintah.

3. Pengawasan

Tujuan pengawasan memiliki arti bahwa akuntansi pemerintah harus terselenggaranya pemeriksaan oleh aparat pengawasan fungsional secara efektif dan efesien.

\subsection{Desa}

Menurut Undang-Undang No. 6 Tahun 2014 tentang Desa, yang menyatakan bahwa desa memiliki hak asal-usul dan hak tradisional dalam mengatur dan mengurus kepentingan masyarakat setempat dan berperan mewujudkan Republik Indonesia Tahun 1945. Dalam perjalan ketatanegaraan Republik Indonesia, Desa telah berkembang dalam berbagai bentuk sehingga perlu dilindungi dan diberdayakan agar menjadi kuat, maju mandiri dan demokratis sehingga dapat menciptakan landasan yang kuat dalam melaksanakan pemerintahan dan pembangunan menuju masyarakat yang adil, makmur dan sejahtera.

\subsection{Pemerintahan Desa}

Dalam peraturan Menteri Dalam Negeri Nomor 4 tahun 2007 mendefinisikan pemerintah desa adalah penyelenggaraan urusan pemerintahan oleh pemerintah desa dan badan permusyawaratan desa dalam mengatur dan mengurus kepentingan masyarakat setempat berdasarkan asal-usul dan adat istiadat setempat yang diakui dan dihormati dalam sistem pemerintahan Negara Kesatuan Republik Indonesia. 


\subsection{Pengelolaan Keuangan Desa}

Menurut Peraturan Menteri Dalam Negeri Nomor 113 Tahun 2014 tentang Pengelolaan keuangan Desa. Keuangan desa dikelola berdasarkan asas-asas transparan, akuntabel, partisipatif, serta dilakukan dengan tata tertib dan disiplin anggaran. Pengelolaan keuangan desa, dikelola dalam masa satu tahun anggaran yakni mulai tanggal 1 januari sampai dengan tanggal 31 Desember. Pengelolaan keuangan Desa meliputi: Perencanaan, pelaksanaan, penatausahaan, pelaporan dan pertanggungjawaban.

\subsection{Anggaran Pendapatan Dan Belanja Desa (APBDes)}

Andi (2016) menyatakan Anggaran Pendapatan Dan Belanja Desa atau APBDes adalah rencana keuangan tahunan pemerintahan desa yang dibahas dan disetujui bersama oleh pemerintah desa dan badan permusyawaratan desa, dan ditetapkan dengan peraturan desa.

\subsection{Penelitian Terdahulu}

1. Elsa Dwi Wahyu Dewanti (2015) dengan judul Analisis Perencanaan Pengelolaan Keuangan Desa Studi kasus di Desa Boreng Kecamatan Lumanjang Kabupaten Luwanjang. Tujuan penelitian untuk mengetahui proses perencanaan pengelolaan keuangan di Desa Boreng. Metode yang digunakan analisis kualitatif. Hasil penelitian menunjukkan bahwa proses perencanaan pengelolaan keuangan yang ada di Desa Boreng belum sepenuhnya sesuai dengan Permendagri No.37 Tahun 2007.

2. Dina Aji Atmaja (2016) dengan judul Analisis Keuangan dan Kekayaan Desa Studi kasus di Desa Plesungan Kecamatan Gondangrojo Kabupaten Karanganyar. Tujuan penelitian untuk mengetahui proses pengelolaan keuangan dan kekayaan Desa Plesungan. Metode yang digunakan analisis kualitatif. Hasil penelitian menunjukkan bahwa proses pengelolaan dan kekayaan desa yang belum sesuai dengan undang-undang.

3. Rianty Pratiwi (2015) dengan judul Implementasi Pengelolaan Keuangan dana desa yang bersumber dari APBN 2015. Tujuan penelitian untuk mengatahui kesesuaian implementasi pengelolaan keuangan dengan peraturan yang mendasari. Metode yang digunakan analisi kualitatif. Hasil penelitian menunjukkan bahwa aktivitas perencanaan penganggaran, pelaksanaan, penatausahaan serta pelaporan dan peratanggungjawaban telah diselengarakan sesuai dengan asas yang berlaku.

\section{PENELITIAN}

\subsection{Jenis Penelitian}

Penelitian ini termasuk pada jenis penelitian deskriptif. Metode deskriptif sebagai metode yang digunakan untuk menggambarkan atau menganalisis tetapi tidak digunakan untuk membuat kesimpulan yang lebih luas (Sugiyono, 2014:3)

\subsection{Tempat dan Waktu penelitian}

Tempat penelitian akan dilakukan di Desa Inobonto II Kecamatan Bolaang Kabupaten Bolaang Mondondow (BOLMONG) dengan alamat: Jln Trans sulawesi. Waktu penelitian dilaksankan pada bulan Mei 2017.

\subsection{Metode pengumpulan data \\ Jenis Data}

Menurut Kuncoro (2009:124) data berdasarkan jenis terbagi dua, yaitu sebagai berikut. 
1. Data kuantitatif, yaitu data yang dinyatakan dalam bentuk numerik seperti data laporan keuangan, data arus kas dan lain sebagainya. Dalam penelitian ini adalah data dalam bentuk laporan keuangan.

2. Data Kualitatif, yaitu data yang tidak dinyatakan dalam bentuk numerik tetapi berupa gambaran deskriptif dalam bentuk uraian seperti gambaran umum perusahaan, kegiatan operasional perusahaan dan data kepustakaan.

\section{Sumber Data}

Dua macam sumber data yang digunakan dalam sebuah penelitian adalah sebagai berikut:

1. Data primer, merupakan sumber data penelitian yang diperoleh secara langsung dari sumber asli (atau tidak dari media perantara) data primer dapat berupa subjek (orang) secara individual atau kelompok. Kejadian atau kegiatan dan hasil-hasil pengujian. Berupa pemerintah desa, catatan-catatan pengelolaan keuangan pemerintah desa serta wawancara dengan kepala desa dan perangkat desa mengenai berbagai program pemerintah desa.

2. Data sekunder, merupakan data penelitian yang diperoleh peneliti secara tidak langsung melalui media perantara (diperoleh dan dicatat oleh pihak lain). Data sekunder umumnya berupa bukti, catatan, atau laporan yang telah tersimpan dalam arsip yang dipublikasikan dan yang tidak dipublikasikan. Berupa laporan keuangan sesuai dengan konsep standar Akuntansi Pemerintahan dan dokumen-dokumen lainnya yang diperlukan dari studi kepustakaan.

\subsection{Teknik Pengumpulan Data}

1. Wawancara

2. Observasi

3. Dokumentasi

\subsection{Metode Analisis}

Dalam penelitian ini, data di analisis dengan menggunakan metode kualitatif yang dimulai dari pengelolaan data, penguraian hasil penelitian secara deskriptif dan menarik kesimpulan yang bersifat kualitatif berdasarkan perbandingan antara teori dan fakta yang ada di Desa Inobonto II. Adapun data-data yang diperoleh berupa proses penyusunan program dan anggaran pemerintah desa inobonto II selanjutnya dalam menganalisi skripsi ini, dilihat kesesuaian anatara perencanaan, pelaksanaan, penatausahaan, pelaporan dan pertanggungjwaban keuangan didesa inobonto II dengan perencanaan, pelaksanaan, penatausahaan, pelaporan dan pertanggungjawaban keuangan dalam PERMENDAGRI Nomor 113 Tahun 2014, kemudian dianalisis penerapannya sehingga dapat ditarik suatu kesimpulan.

\section{HASIL ANALISIS DAN PEMBAHASAN}

\subsection{Hasil Penelitian}

\section{Proses Perencanaan APBDes Desa Inobonto II}

Proses perencanaaan keuangan Desa Inobonto II mengacu pada perencanaan pembangunan Kabupaten/Kota meliputi Rencana Pembangunan Jangka Menengah Desa (RPJMDes) yang disusun secara berjangka dan ditetapkan dengan peraturan desa. Rencana Pembangunan Jangka Menengah Desa (RPJMDes) dalam jangka waktu 6 (enam) tahun melalui forum Musyawarah Perencanaan Pembangunan Desa (Musrenbangdes). Musrenbangdes adalah forum musyawarah yang membahas usulan-usulan rencana kegatan pembangunan desa yang berpedoman pada prinsip perencanaan pembangunan partisipasi 
masyarakat desa, serta transparansi pemerintah kepada masyarakat. Musrenbangdes diadakan untuk membahas dan menyepakati rencanan kerja pemerintah desa (RKPDes) dalam jangka pendek untuk 1 (satu) tahun berdasarkan RPJMDes.

\section{Proses Pelaksanaan APBDes Desa Inobonto II}

Proses pelaksanaan APBDes merupakan rangkaian kegiatan untuk melaksanakan APBDes dalam satu anggaran yang dimulai dari 1 Januari sampai dengan 31 Desember. Dalam anggaran pendapatan dan belanja desa (APBDes) disusunlah rencana anggaran biaya (RAB) untuk setiap kegiatan yang menjadi dasar pengajuan surat permintaan pembayaran (SPP). Semua pendapatan Desa Inobonto II dilaksanakan melalui rekening kas desa. Setiap pendapatan desa harus didukung oleh bukti yang lengkap dan sah. Khusus bagi desa yang belum memiliki pelayanan perbankan diwilayahnya maka pengaturannnya diserahkan kepada daerah. Program dan kegiatan yang masuk di desa merupakan sumber penerimaan dan pendapatan desa dan wajib dicatat dalam APBDes.

\section{Proses Pertanggungjawaban APBDes Desa Inobonto II}

Proses pertanggungjawaban Desa Inobonto II, bendahara desa wajib melaporakan penggunaan dana Anggaran Pendapatan dan Belanja Desa (APBDes) kepada kepala Desa. Tanggungjawab tersebut dibuat secara terperinci dan sesuai dengan ketentuan yang berlaku. Kewajiban untuk melaporakan pertanggungjawaban pengelolaan keuangan desa menuntut bagi bendahara untuk mampu menginterpretasikan paraturan-peraturan tentang pertanggungjawaban. Pertanggungjawaban pelaksanaan APBDes terdiri dari penetapan pelaksanaan APBDes dan penyampaian laporan pertanggungjawaban pelaksanaan APBDes.

\subsection{Pembahasan}

\section{Analisis Perencanaan Angaaran Pendapatan dan Belanja Desa Inobonto II Dikaitkan} Dengan Permendagri No.113 Tahun 2014

Hasil penelitian yang diperoleh dari Desa Inobonto II bahwa perencanaan keuangan desa telah sesuai dengan Permendagri No.113 Tahun 2014 yaitu Sekretaris Desa Menyusun rancangan Peraturan Desa tentang APBDes berdasarkan RKPDes untuk tahun berkenan. Sekretaris Desa menyampaikan rancangan Peraturan Desa tentang APBDe berdasarkan RKPDes kepada Kepala Desa. Rancangan Peraturan Desa tentang APBDes dibahas dan disepakati Kepala Desa dan badan permusyawaratan desa (BPD). Rancangan Peraturan Desa tentang APBDes disepakati bersama paling lambat bulan oktober tahun berjalan. Rancangan PERDES tentang APBDes yang telah disepakati bersama disampaikan oleh Kepala Desa kepada Bupati/Walikota mealui camat atau sebutan lain paling lambat 3 (tiga) hari sejak disepakati untuk dievaluasi. Bupati/Walikota menetapkan hasil rancangan APBDes paling lambat 20 (dua puluh) hari kerja kepada kepala desa sejak diterima rancangan peraturan desa tentang APBDes

\section{Analisis Pelaksanaan Angaaran Pendapatan dan Belanja Desa Inobonto II Dikaitkan Dengan Permendagri No.113 Tahun 2014}

Desa Inobonto II dalam pelaksanaan APBDes telah sesuai dengan Permendagri Nomor 113 Tahun 2014 yaitu Sekretaris Desa menyusun rancangan Peraturan Desa tentang APBDes berdasarkan RKPDes tahun berkenan. Sekretaris Desa menyampaikan rancangan Peraturan Desa tentang APBDes kepada kepala desa. Rancangan Peraturan Desa tentang APBDes dibahas dan disepakati oleh Kepala Desa dan badan permusyarawaratan desa (BPD). Rancangan Peraturan Desa tentang APBDes disepakati bersama paling lambat bulan oktober tahun berjalan. Rancangan PERDES tentang APBDes yang telah disepakati bersama disampaikan oleh Kepala Desa kepada Bupati/Walikota melalui camat atau sebutan lain 
paling lambat 3 (tiga) hari sejak disepakati untuk dievaluasi. Bupati/Walikota menetapkan hasil rancangan APBDes paling lama 20 (dua puluh) hari kerja kepada kepala desa sejak diterimanya rancangan peraturan desa tentang APBDes.

\section{Analisis Pertanggungjawaban Angaaran Pendapatan dan Belanja Desa Inobonto II Dikaitkan Dengan Permendagri No.113 Tahun 2014}

Hasil penelitian yang diperoleh dari lapangan pertanggungjawaban keuangan Desa Inobonto II, dimana dalam hal ini terjadi ketidaaksesuaian yaitu pertanggungjawaban belum diinformasikan kepada seluruh masyarakat Desa Inbonto II, berdasarkan Permendagri No.113 Tahun 2014 pasal 40 yang mengatur bahwa laporan pertanggungjawaban realisasi pelaksanaan APBDes diinformasikan kepada masyarakat secara tertulis dan dengan media yang mudah diakses oleh masyarakat. Hal ini, inspektorat mendapat temuan di Desa Inobonto II, mengenai Register Surat Permintaan Pembayaran (SPP) Tahun Anggaran 2016 karena jumlah yang tidak sesuai dengan Register Kwitansi Pembayaran Tahun Anggaran 2016 dan telah diberikan kesempatan untuk Desa Inobonto II dalam melengakapi dokumen pendukungnya. Hasil dari pemeriksaan Inspektorat ke Desa diberikan kepada Bupati Bolaang Mongondow sebagai tanda bukti telah diperiksa.

\section{KESIMPULAN DAN SARAN}

\subsection{Kesimpulan}

Berdasarkan pembahasan yang telah disajikan pada bab sebelumnya maka dapat ditarik kesimpulan sebagai berikut :

1. Proses pengelolaan keuangan desa Inobonto II, kepala desa, sekretaris desa, dan bendahara desa telah melaksanakan tugas-tugasnya dalam mengelola keuangan desa dengan baik. Dimana tahap perencanaan dilaksanakan oleh sekretaris desa, tahap pelaksanaan dan penatausahaan dilakukan oleh bendahara desa, tahap pelaporan dan pertanggungjawaban dilakukan oleh kepala desa.

2. Pengelolaan keuangan desa Inobonto II secara umum sudah baik, akan tetapi terjadi ketidaksesuaian pada tahap pertanggungjawaban. Dimana pertanggungjawaban belum bisa dipublikasikan kepada seluruh masyarakat Inobonto II. Hal tersebut dikarena tidak adanya media informasi yang dapat dengan mudah diakses oleh masyarakat, seperti papan informasi desa yang dapat memuat informasi penting termasuk pengelolaan APBDes.

3. Pelaksanaan sistem keuangan desa Inobonto II belum dilaksanakan sesuai dengan Permendagri No .113 Tahun 2014 tentang Pengelolaan Keuangan Desa, antara lain sebagai berikut:

a. Perangkat desa belum bisa mengelola dokumen pendukung disebabkan terjadi kelalaian sehingga terdapat perbedaan mengenai Register Surat Permintaan Pembayaran (SPP) Tahun Anggaran 2016 dan Register Kwitansi Pembayaran Tahun Anggaran 2016.

b. Kurangnya pemantapan sumber daya manusia yang dapat dilakukan melalui pelatihan keterampilan menggunakan sarana pendukung aktivitas pengelolaan keuangan desa seperti SIMDes. Dan perlu adanya peningkatan dalam hal pengendalian internal dalam mengelola keuangan desa.

\subsection{Saran}

Berdasarkan kesimpulan diatas peneliti memberikan saran sebagai berikut:

1. Kiranya untuk Tahun 2017 dalam pembuatan pengelolaan keuangan APBDes, Desa Inobonto II lebih disesuaikan dengan ketentuan yang berlaku dalam Permendagri No. 113 Tahun 2014 terlebih khusus dalam proses pertanggungjawaban. Agar pengelolaan 
keuangan Desa dapat terwujud dengan efektif dan efisiensi serta dapat bermanfaat bagi pembangunan desa.

2. Pemerintah desa inobonto II lebih meningkatkan asas keterbukaan dan transparansi dalam melakukan pengeloan keuangan desa terutama kepada masyarakat.

3. Diharapkan pelaksanaan sistem keuangan desa inobonto II disesuaikan lagi dengan Peraturan Menteri Dalam Negeri Nomor 113 Tahun 2014 tentang pengelolaan keuangan desa, yaitu:

a. Melengkapi dokumen pendukungnya sehingga pada tahun anggaran berikutnya tidak terjadi temuan masalah

b. Pentingnya sumber daya manusia juga menjadi hal yang perlu diperhatikan karena SDM yang berkualitas dan kompoten sangat dibutuhkan agar mampu bekerja dengan baik dan menghasilkan pengelolaan keuangan yang berkualitas.

4. Selain itu untuk peneliti selanjutnya agar dapat melakukan penelitian pada beberapa desa yang lain di kecamatan Bolaang Kabupaten Bolaang Mongondow agar dapat mengambarkan secara umum dan luas penyajian pengelolaan keuangan pemerintah desa.

\section{DAFTAR PUSTAKA}

Atmaja, Aji, Dinar. 2016. "Analisis Pengelolaan Keuangan dan Kekayaan Desa"

Abdul Halim, 2010. Manajemen Keuangan Daerah, Yogyakart: Unit Penerbit dan Percetakan Akademi Manajemen Perusahaan YKPN.

Aliyah, Nahar. 2013. "Pengaruh Penyajian Laporan Keuangan Daerah dan Aksesibilitas Laporan Keuangan Daerah Terhadap Transparansi dan Akuntabilitas Pengelolaan Keuangan Daerah Kabupaten Jepara" Jurnal Akuntansi \& Auditing 137. Vol. 8 No. 2 Mei 2012 Hal 97-189.

Arif, Muhammad, 2007. Tata Cara Pengelolaan Keuangan Desa dan Pengelolaan Kekayaan Desa. Pekan baru: Red Post Press.

Andi, Acep, Dicky.2016. "Akuntansi Dalam Perspektif Pengelolaan Keuangan Desa"

Adam Amirullah, 2016. Analisis Pengelolaan Keuangan Desa Berdasarkan Permendagri 113 Tahun 2014, di Desa Brumbungan Kidul Kecamatan Maron Kabupaten Probolinggo, Fakultas Ekonomi Dan Bisnis Universitas Muhammadiyah Malang.

Bachtiar, Arif, Muchlis, Iskandar, 2012. Akuntansi Pemerintahan, Jakarta: Selemba Empat. 